\title{
Impact of school closures and re-openings on COVID-19 transmission
}

\author{
Maryem El Jaouhari ${ }^{1}$, Rojiemiahd Edjoc ${ }^{1 *}$, Lisa Waddell2 ${ }^{2}$ Patricia Huston ${ }^{3}$, Nicole Atchessi ${ }^{1}$, \\ Megan Striha ${ }^{1}$, Samuel Bonti-Ankomah ${ }^{1}$
}

\begin{abstract}
Background: Globally, the education of students at primary and secondary schools has been severely disrupted by the implementation of school closures to reduce the spread of coronavirus disease 2019 (COVID-19). The effectiveness of school closures in reducing transmission of COVID-19 and the impact of re-opening schools are unclear.

Methods: Research criteria for this rapid review included empirical studies, published or pre-published worldwide before January 25, 2021, that assessed the effectiveness of school closures in reducing the spread of COVID-19 and the impact of school re-openings on COVID-19 transmission.

Results: Twenty-four studies on the impact of school closures and re-openings on COVID-19 transmission were identified through the seven databases that were searched. Overall the evidence from these studies was mixed and varied due to several factors such as the time of implementation of public health measures, research design of included studies and variability among the levels of schooling examined.
\end{abstract}

Conclusion: Preliminary findings suggest that school closures have limited impact on reducing COVID-19 transmission, with other non-pharmaceutical interventions considered much more effective. However, due to the limitations of the studies, further research is needed to support the use of this public health measure in response to the COVID-19 pandemic.
This work is licensed under a Creative Commons Attribution 4.0 International License.

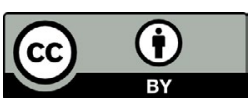

Affiliations

${ }^{1}$ Health Security Regional Operations Branch, Public Health Agency of Canada, Ottawa, ON

${ }^{2}$ National Microbiology Laboratory, Public Health Agency of Canada, Winnipeg, MB

${ }^{3}$ Office of Chief Science Officer, Public Health Agency of Canada, Ottawa, ON

\section{*Correspondence:}

rojiemiahd.edjoc@phac-aspc. gc.ca

Suggested citation: El Jaouhari M, Edjoc R, Waddell L, Huston P, Atchessi N, Striha M, Bonti-Ankomah S. Impact of school closures and re-openings on COVID-19 transmission. Can Commun Dis Rep

2021;47(12):515-23. https://doi.org/10.14745/ccdr.v47i12a02

Keywords: COVID-19, SARS-CoV-2, school closures, school re-opening, non-pharmaceutical intervention

\section{Introduction}

As of March 11, 2020, the World Health Organization has declared the coronavirus disease 2019 (COVID-19) outbreak a pandemic (1). Globally, jurisdictions started to implement a variety of non-pharmaceutical interventions (NPIs) to limit the spread and the impact of COVID-19 disease caused by severe acute respiratory syndrome coronavirus 2 (SARS-CoV-2). Closing schools was one of the NPIs implemented; however, these closures not only disrupted the education and daily routines of students, but also the lives of teachers and parents.

While school closures have been implemented to combat the spread of COVID-19, they were also associated with negative effects on student's mental health and academic progress and lead to increased stress in parents and teachers (2). With a lack of school-based peer interactions and daily routines, it has been reported that students experience increased distress, loneliness, anxiety and depressive symptoms $(2,3)$. School routines are crucial for maintaining the well-being of students, especially those with mental health or special education needs (4). In addition, school closures have been associated with reduced academic achievement due to delayed educational progress $(3,5,6)$. It is uncertain whether virtual learning is equally effective and many students from low-income households lack access to, and accommodations with, online materials (6).

Given the negative impacts of school closures, it is important to consider whether they are significantly effective in reducing the impact of COVID-19. Initially, it was assumed that school closures would be effective in mitigating the spread of COVID-19 based on the evidence from both seasonal and epidemic influenza $(7,8)$. In contrast, modelling studies conducted in Ontario and across Canada during the first and second waves found that school closures had limited impact on reducing the transmission of COVID-19 compared with other NPIs (9-11). Other modelling studies reported modest effects of school closures in delaying peak case numbers early in the pandemic $(12,13)$, while some 
studies showed a smaller magnitude of effect when compared with other NPIs $(14,15)$. Early modelling studies relied on the underlying assumption that there is a low transmission risk in children. Although modelling studies are excellent for making informed predictions, their accuracy is dependent on the assumptions and the quality of data used. Overall, there was a need to assess the potential impacts of school closures in reducing the spread of COVID-19.

This review summarizes empirical studies on the effectiveness of school closures and the impact of re-opening schools in reducing community transmission of COVID-19 and decreasing the incidence of COVID-19 in primary and secondary schools. The principal focus of this article was the impact of primary and secondary school closures, although if studies also included data from other types of schools this was included as well.

\section{Methods}

Our research criteria included empirical studies that assessed the impact of school closures and/or re-openings on COVID-19 that were published before January 25, 2021. Predictive modelling studies were excluded. Searches to retrieve relevant articles were conducted in PubMed, Scopus, BioRxiv, MedRxiv, ArXiv, SSRN and Research Square, by the Emerging Science Group of the Public Health Agency of Canada. Search terms included the following: school AND closure OR re-opening within a database of COVID-19 literature that is updated daily. References were also used to search for additional relevant studies. Included literature was confined to English and French languages. Articles $(n=966)$ were then screened for relevance. A total of five observational studies and nineteen ecological studies were found to be relevant (see Appendix Table A1 and Table A2).

\section{Results}

Twenty-four articles published prior to January 25, 2021 on the impact of school closures and/or re-openings on the spread of COVID-19, were identified. These included a cross-sectional study $(16)$, two cohort studies $(17,18)$, two cluster and outbreak investigations $(19,20)$ and 19 ecological studies. Eleven of these studies are preprints or studies that have not yet been peer-reviewed. All studies identified in this review pre-date the identification of variants of concern.

Most observational studies assessing the impact of school closures/re-openings on the spread of COVID-19 in schools reported no significant effects (see Appendix Table A1). Four studies found no difference in incidence of cases both before and after closing schools for the holidays, following children who stayed at home vs those who went to school with strict surveillance, or following school re-opening (16-19). An outbreak investigation study reported a large outbreak from a high school in Israel, but this was confounded by the fact that the mask mandate was lifted just as there was a heatwave, which may have affected compliance with other recommended public health measures (20). Furthermore, it was noted that there was overcrowding in the high school that limited physical distancing, and extracurricular activities were not banned.

Of the ecological studies assessing community transmission (see Appendix Table A2), ten were conducted across multiple countries, five in the United States, two in Asia and two in Europe. Five studies reported that school closures and re-openings were not significantly associated with reduction in the transmission and incidence of COVID-19 and were much less effective in reducing transmission when compared with other NPIs (21-25). Four studies reported a reduction in the incidence of COVID-19 in the community ranging from $8 \%$ to $62 \%$ following school closures (26-29). Other studies reported a significant reduction in the effective reproduction number $\left(R_{t}\right)$ (30-32). Three studies attributed significant reductions in mortality to school closures $(29,33,34)$ and one study reported increased mortality with delayed school closures (35).

\section{Discussion}

Overall, the evidence from these studies was mixed and varied due to several factors. Based on the findings of the observational studies assessing the incidence of COVID-19 in schools, school closures and re-openings did not significantly contribute to COVID-19 transmission when infection prevention and control measures (IPAC) were implemented in schools. The IPAC measures implemented by the schools were similar across most of the observational studies and included masks, physical distancing, frequent cleaning, reduced class sizes and improved hand hygiene. The implementation of these measures in schools have been reported to act as a mediating variable because of the reduced transmission and risk of infection with IPAC measures (36).

The findings from the ecological studies assessing community transmission were inconsistent, with some studies reporting that school closures/re-openings were not significantly associated with reduction in transmission (21-25), and other studies reporting a significant reduction in $\mathrm{R}_{\mathrm{t}}(30-32)$ and mortality $(29,33,34)$. In several of these ecological studies, it was reported that other NPIs such as lockdowns, gathering bans, mask mandates, non-essential business closure and travel restrictions were more effective than school closures in reducing the transmission of COVID-19. Ecological studies are considered a low level of evidence due to the research design, the multiple confounding factors and the high degree of variability in the results. All of the ecological studies included in this review analyzed data on school closures/re-openings early in the pandemic, between January-August 2020, when multiple NPIs were implemented simultaneously. Therefore, it was not possible to isolate the impact of school closures/re-openings on the 
number of cases of COVID-19 in the community. Additionally, only one of the ecological studies described if there was adherence to IPAC measures in the schools (25). These factors likely contribute to the heterogeneity between studies.

An important limitation of this review was the inconsistencies in the levels of schooling that were included in each study, which may have increased the variability in measures of how effective school closures were across studies. Most studies did not provide information on what schools were included when determining the impact of school closures on the spread of COVID-19. Some studies measured primary and secondary school closures alone and some measured them in combination with post-secondary schools. The risk of transmission may have varied significantly between students in primary and secondary schools because of potential differences in their behaviours and adherence to IPAC measures with resultant difference in reduction of viral transmission. Transmission was found to be lower in primary schools relative to secondary schools, based on the results of one study in a review that assessed this (19). Although not specifically stated in the previous study, their results were in line with what we know about the use of IPAC to limit transmission in these settings (37). Additionally, the relative impact of school closures and re-openings have been shown to vary according to the time of implementation, level of community transmission, and the structure of populations from different countries.

Based on the empirical evidence summarized in this article, school closures had a small effect on limiting the spread of COVID-19 in schools and the community and appeared to be much less effective than other NPIs. These findings are also consistent with modelling studies conducted across Canada (9-15). The implementation of school closures is currently based on when the transmission of COVID-19 in the community is high-as dictated by local health jurisdictions; however, the role of school closures and re-opening in areas with low community transmission is less clear and should be studied further.

School closures may be associated with negative effects on student's mental health and academic progress (2); thus, public health decision makers should consider if the apparent low efficacy of school closures in reducing transmission outweighs the many negative consequences on students' well-being. Overall, the confidence in this evidence is low given that the studies in this review vary by several factors and were conducted at different times and in a number of countries. Finally, the study period of this review is also a limitation, as there are marked differences in the $3^{\text {rd }}$ and $4^{\text {th }}$ waves compared with the $1^{\text {st }}$ and $2^{\text {nd }}$ waves of COVID-19 with the introduction of more transmissible variants of concern. How the present evidence will compare with that obtained during periods of the spread of more transmissible variants of concern is not known at this time and will require further study.

\section{Conclusion}

The findings of this review may have implications for public health decision making and future research on mitigation strategies for schools. The preliminary evidence provided in this review suggests that school closures and re-openings may have only a limited impact on the transmission of COVID-19 within a community. However, there is still a high degree of uncertainty due to the high variation in the methodology and results across the various studies. Additional research is needed to further explore more systematically the impacts of school closures and to determine how and when they may be used most effectively in controlling the epidemic.

Important knowledge gaps to consider are how 1) the presence of new variants of concern and 2) the rollout of COVID-19 vaccinations will impact the transmission of COVID-19 within the schools and communities. The evidence presented in this article pre-dates the introduction of variants of concern; therefore, additional research is needed to understand how the emergence and spread of these variants will impact the effectiveness of school closures or what the impact of school re-openings will have on the spread of COVID-19.

\section{Authors' statement}

MEJ - Methodology, investigation, writing-original draft $\mathrm{RE}$ - Conceptualization, writing-review and editing, supervision LW - Writing-review and editing $\mathrm{PH}-$ Writing-review and editing NA - Writing-review and editing MS - Writing-review and editing SB-A - Writing-review and editing

\section{Competing interests}

None.

\section{Acknowledgements}

We would like to acknowledge the work of the Emerging Science Group for allowing us to collaborate with them on this important issue.

\section{Funding}

None. 


\section{References}

1. World Health Organization. WHO Director-General's opening remarks at the media briefing on COVID-19 - 11 March 2020. Geneva (CH): WHO; 2020 (accessed 2021-05-27). https://www.who.int/director-general/ speeches/detail/who-director-general-s-opening-remarks-atthe-media-briefing-on-covid-19---11-march-2020

2. Viner R, Russell S, Saulle R, Croker H, Stansfeld C, Packer J, Nicholls D, Goddings A-L, Bonell C, Hudson L, Hope S, Schwalbe N, Morgan A, Minozzi S. Impacts of school closures on physical and mental health of children and young people: a systematic review. medRxiv. 2021;2021.02.10.21251526. DOI

3. Bahn GH. Coronavirus disease 2019, school closures, and children's mental health. Soa Chongsonyon Chongsin Uihak 2020;31(2):74-9. DOI PubMed

4. Lee J. Mental health effects of school closures during COVID-19. Lancet Child Adolesc Health 2020;4(6):421. DOI PubMed

5. London School Economics and Polital Science. Eyles A Gibbons S, Montebruno P. Covid-19 school shutdowns: What will they do to our children's education? LSE; 2020. http://eprints.Ise.ac.uk/104675/3/Eyles_covid_19_school_ shutdowns_published.pdf

6. Kuhfeld M, Soland J, Tarasawa B, Johnson A, Ruzek E, Liu J. Projecting the Potential Impact of COVID-19 School Closures on Academic Achievement. Educ Res 2020;49(8):549-65. DOI

7. National Collaborating Centre for Infectious Diseases. Isfeld-Kiely H, Moghadas S. Effectiveness of School Closure for the Control of Influenza A Review of Recent Evidence. NCCID; 2014. https://nccid.ca/publications/effectiveness-ofschool-closure-for-the-control-of-influenza/

8. World Health Organization. Non-pharmaceutical public health measures for mitigating the risk and impact of epidemic and pandemic influenza. Geneva $(\mathrm{CH})$ : WHO; 2019 (accessed 2021-04-27). http://www.who.int/influenza/ publications/public_health_measures/publication/en/

9. Abdollahi E, Haworth-Brockman M, Keynan Y, Langley JM, Moghadas SM. Simulating the effect of school closure during COVID-19 outbreaks in Ontario, Canada. BMC Med 2020;18(1):230. DOI PubMed

10. Naimark D, Mishra S, Barrett K, Khan YA, Mac S, Ximenes R, Sander B. Simulation-Based Estimation of SARS-CoV-2 Infections Associated With School Closures and Community-Based Nonpharmaceutical Interventions in Ontario, Canada. JAMA Netw Open 2021;4(3):e213793. DOI PubMed

11. $\mathrm{Ng} \mathrm{V}$, Fazil A, Waddell LA, Bancej C, Turgeon $P$, Otten A, Atchessi N, Ogden NH. Projected effects of nonpharmaceutical public health interventions to prevent resurgence of SARS-CoV-2 transmission in Canada. CMAJ 2020;192(37):E1053-64. DOI PubMed
12. Davies NG, Kucharski AJ, Eggo RM, Gimma A, Edmunds WJ; Centre for the Mathematical Modelling of Infectious Diseases COVID-19 working group. Effects of non-pharmaceutical interventions on COVID-19 cases, deaths, and demand for hospital services in the UK: a modelling study. Lancet Public Health 2020;5(7):e375-85. DOI PubMed

13. Koo JR, Cook AR, Park M, Sun Y, Sun H, Lim JT, Tam C, Dickens BL. Interventions to mitigate early spread of SARS-CoV-2 in Singapore: a modelling study. Lancet Infect Dis 2020;20(6):678-88. DOI PubMed

14. Courtemanche C, Garuccio J, Le A, Pinkston J, Yelowitz A. Strong social distancing measures in the United States reduced the covid-19 growth rate. Health Aff (Millwood) 2020;39(7):1237-46. DOI PubMed

15. Garchitorena A, Gruson H, Cazelles B, Karki T, Sudre B, Roche B. Integrated packages of non-pharmaceutical interventions increased public health response efficiency against COVID-19 during the first European wave: evidence from 32 European countries. medRxiv. 2020; 2020.08.17.20174821v2. DOI

16. Kriger O, Lustig Y, Cohen C, Amit S, Biber A, Barkai G, Talmi L, Gefen-Halevi S, Mechnik B, Regev-Yochay G. The Sheba Medical Center healthcare workers' children's school: can we open schools safely? Clin Microbiol Infect 2021;27(3):474.e1-3. DOI PubMed

17. Gandini S, Rainisio M, Luisa lannuzzo M, Bellerba F, Cecconi F, Scorrano L. No evidence of association between schools and SARS-CoV-2 second wave in Italy. med Rxiv. 2020; 2020.12.16.20248134v2. DOI

18. Fontanet A, Grant R, Tondeur L, Madec Y, Grzelak $L$, Cailleau I, Ungeheuer M-N, Renaudat C, Fernandes Pellerin S, Kuhmel L, Staropoli I, Anna F, Charneau P, Demeret C, Bruel T, Schwartz O, Hoen B. SARS-CoV-2 infection in primary schools in northern France: A retrospective cohort study in an area of high transmission. medRxiv. 2020;2020.06.25.20140178v2. DOI

19. Larosa E, Djuric O, Cassinadri M, Cilloni S, Bisaccia E, Vicentini M, Venturelli F, Giorgi Rossi P, Pezzotti P, Bedeschi E; Reggio Emilia Covid-19 Working Group. Secondary transmission of COVID-19 in preschool and school settings in northern Italy after their reopening in September 2020: a population-based study. Euro Surveill 2020;25(49):2001911. DOI PubMed

20. Stein-Zamir C, Abramson N, Shoob H, Libal E, Bitan M, Cardash T, Cayam R, Miskin I. A large COVID-19 outbreak in a high school 10 days after schools' reopening, Israel, May 2020. Euro Surveill 2020;25(29):2001352. DOl PubMed

21. An B, Porcher S, Tang SY, Kim E. Effects of Early Mask Mandates and Other Policy Interventions on COVID-19 Infections. Research Square. 2021. DOI

22. Liu X, Xu X, Li G, Xu X, Sun Y, Wang F, Shi X, Li X, Xie G, Zhang L. Differential impact of non-pharmaceutical public health interventions on COVID-19 epidemics in the United States. BMC Public Health 2021;21(1):965. DOI PubMed 
23. Iwata K, Doi A, Miyakoshi C. Was school closure effective in mitigating coronavirus disease 2019 (COVID-19)? Time series analysis using Bayesian inference. Int J Infect Dis 2020;99:57-61. DOI PubMed

24. Wieland T. A phenomenological approach to assessing the effectiveness of COVID-19 related nonpharmaceutical interventions in Germany. Saf Sci 2020;131:104924.

DOI PubMed

25. Ehrhardt J, Ekinci A, Krehl H, Meincke M, Finci I, Klein J, Geisel B, Wagner-Wiening C, Eichner M, Brockmann SO. Transmission of SARS-CoV-2 in children aged 0 to 19 years in childcare facilities and schools after their reopening in May 2020, Baden-Württemberg, Germany. Euro Surveill 2020;25(36):2001587. DOI PubMed

26. Banholzer $N$, van Weenen $E$, Lison $A$, Cenedese $A$, Seeliger A, Kratzwald B, Tschernutter D, Salles JP, Bottrighi P, Lehtinen S, Feuerriegel S, Vach W. Estimating the effects of non-pharmaceutical interventions on the number of new infections with COVID-19 during the first epidemic wave. PLoS One 2021;16(6):e0252827. DOI PubMed

27. Banholzer N, van Weenen E, Kratzwald B, Seeliger A, Tschernutter D, Bottrighi P, Cenedese A, Salles JP, Vach W, Feuerriegel S. Impact of non-pharmaceutical interventions on documented cases of COVID-19. medRxiv. 2020; 2020.04.16.20062141v3. DOI

28. Brauner JM, Mindermann $S$, Sharma $M$, Johnston $D$, Salvatier J, Gavenčiak T, Stephenson AB, Leech G, Altman G, Mikulik V, Norman AJ, Monrad JT, Besiroglu T, Ge H, Hartwick MA, Teh YW, Chindelevitch L, Gal Y, Kulveit J. Inferring the effectiveness of government interventions against COVID-19. Science 2021;371(6531):eabd9338. DOI PubMed

29. Auger KA, Shah SS, Richardson T, Hartley D, Hall M, Warniment A, Timmons K, Bosse D, Ferris SA, Brady PW, Schondelmeyer AC, Thomson JE. Association Between Statewide School Closure and COVID-19 Incidence and Mortality in the US. JAMA 2020;324(9):859-70. DOI PubMed

30. Esra R, Jamieson L, Fox MP, Letswalo D, Ngcobo N, Mngadi S, Estill J, Meyer-Rath G, Keiser O. Evaluating the impact of non-pharmaceutical interventions for SARS-CoV-2 on a global scale. medRxiv 2020; 2020.07.30.2016439. DOI

31. Dreher N, Spiera Z, Mcauley FM, Kuohn L, Durbin JR, Marayati NF, Ali M, Li AY, Hannah TC, Gometz A, Kostman JT, Choudhri TF. Impact of policy interventions and social distancing on SARS-CoV-2 transmission in the United States. medRxiv. 2020; 2020.05.01.20088179v1. DOI
32. Cowling BJ, Ali ST, Ng TW, Tsang TK, Li JC, Fong MW, Liao Q, Kwan MY, Lee SL, Chiu SS, Wu JT, Wu P, Leung GM. Impact assessment of non-pharmaceutical interventions against coronavirus disease 2019 and influenza in Hong Kong: an observational study. Lancet Public Health 2020;5(5):e279-88. DOI PubMed

33. Stokes, J, Turner AJ, Anselmi L, Morciano M, Hone T. The relative effects of non-pharmaceutical interventions on early Covid-19 mortality: natural experiment in 130 countries. medRxiv.2020; 2020.10.05.20206888v1. DOI

34. Pasdar Z, Pana TA, Ewers KD, Szlachetka WA, Perdomo-Lampignano JA, Gamble DT, Bhattacharya S, Carter B, Myint PK. An Ecological Study Assessing the Relationship between Public Health Policies and Severity of the COVID-19 Pandemic. SSRN Electron J. 2020. https://papers.ssrn.com/abstract=3634847

35. Yehya N, Venkataramani A, Harhay MO. Statewide Interventions and Coronavirus Disease 2019 Mortality in the United States: An Observational Study. Clin Infect Dis 2021;73(7):e1863-9. DOl PubMed

36. Public Health Ontario. Technical Brief. IPAC Recommendations for Use of Personal Protective Equipment for Care of Individuals with Suspect or Confirmed COVID-19. Toronto (ON): PHO; 2021. https://www.publichealthontario. $\mathrm{ca} /$-/media/documents/ncov/updated-ipac-measurescovid-19.pdf?la=en

37. National Collaborating Centre for Methods and Tools. Living Rapid Review Update 17: What is the specific role of daycares and schools in COVID-19 transmission? Hamilton (ON): NCCMT; 2021 (accessed 2021-10-28). https://www. nccmt.ca/covid-19/covid-19-rapid-evidence-service/19

38. Klimek-Tulwin M, Tulwin T. Early school closures can reduce the first-wave of the COVID-19 pandemic development. J Public Health (Berl.) 2020. DOI

39. Papadopoulos DI, Donkov I, Charitopoulos K, Bishara S. The impact of lockdown measures on COVID-19: a worldwide comparison. medRxiv. 2020; 2020.05.22.20106476v2. DOI

40. Jüni $P$, Rothenbühler $M$, Bobos $P$, Thorpe $K E$, da Costa $B R$, Fisman DN, Slutsky AS, Gesink D. Impact of climate and public health interventions on the COVID-19 pandemic: a prospective cohort study. CMAJ 2020;192(21):E566-73. DOl PubMed

41. Krishnamachari B, Morris A, Zastrow D, Dsida A, Harper B, Santella AJ. Effects of Government Mandated Social Distancing Measures on Cumulative Incidence of COVID-19 in the United States and its Most Populated Cities. medRxiv. 2020; 2020.05.22.20110460v1. DOI 


\section{Appendix: Tables}

\section{Appendix Table A1: Summary of observational studies assessing the impact of school closures or re-openings on the transmission of COVID-19 in schools and the community $(n=5)$}

Study

Method

\section{Key outcomes}

Cohort studies $(n=2)$

Gandini (2020) (17)

Prospective cohort study and cross-sectional study

Italy

Sep-Nov 2020

Retrospective cohort study

France

Feb-Apr 2020
This study analyzed the association between school re-opening dates and COVID-19 cases across twenty-one Italian regions by using a database on positive cases in elementary, middle and high schools and SARS-CoV-2 incidence in the general population. IPAC measures included temperature control, hand hygiene, mask mandate for students/staff, physical distancing, ban on sports and music and reduced duration of school.

Several COVID-19 outcomes were measured during school re-openings: growth of incidence, $R_{t^{\prime}}$ and secondary infections.

This retrospective cohort study included primary school pupils, teachers, non-teaching staff, parents and relatives exposed to SARS-CoV-2 in February and March from six schools. IPAC measures were not described.

A questionnaire covering sociodemographic information and history of recent symptoms was completed by participants. Blood samples were also tested for the presence of anti-SARS-CoV-2 antibodies using a flow-cytometry-based assay. Three introductions of SARS-CoV-2 occurred prior to school closures. Spread within schools vs families was investigated in this sero-epidemiological study. IAR was compared between school contacts and family contacts to understand the potential impact of the school closure.
There was no evidence that the second SARS-CoV-2 wave was driven by school re-openings across the regions.

SARS-CoV-2 incidence among students was lower than the general population of all but two Italian regions.

The increase in $R_{t}$ was not associated with the different school opening dates.

School closures implemented in two regions did not affect the decline of $R_{t}$.

IAR was $45 / 510$ (8.8\%), 3/42 (7.1\%), 1/28 (3.6\%), $76 / 641(11.9 \%)$ and $14 / 119(11.8 \%)$ among primary school pupils, teachers, non-teaching staff, parents and relatives, respectively $(p=0.29)$.

No secondary infections from COVID-19 introductions in schools was detected among students and teachers.

Among pupils who were infected, their parents were significantly more likely to be infected $(61.0 \%$ versus $6.9 \% ; p<0.0001)$, The same was identified among relatives of infected pupils compared with non-infected pupils $(44.4 \%$ versus $9.1 \% ; p=0.002)$.

Transmission did not appear to be impacted by the closure of schools.

\section{Cross-sectional studies $(n=1)$}

Kriger (2020) (16)

Cross-sectional study Israel

Mar-May 2020
During a national lockdown, an alternative school was used for healthcare workers' children to attend with strict symptom surveillance. Families with children who remained at home were compared with children at this alternative school. IPAC measures in the school included daily disinfecting, face mask use by staff and frequent hand washing.

This cross-sectional study included 70 children who attended the alternative primary school and 36 who stayed home, along with their 78 parents.

Data was collected through a short questionnaire; nasopharyngeal and oropharyngeal swabs were obtained and tested for SARS-CoV-2 by RT-PCR, and blood was collected for SARS-CoV-2 IgA and $\lg G$ titres.
Symptoms were reported in approximately $16 \%$ of children in both groups: those who attended the school $(n=11 / 70)$ and those who did not $(n=6 / 36)$.

Positive serology tests showing previous exposure was detected in less than $2 \%$ of each group and they were not significantly different from each other.

There was no evidence of increased infection in those at school compared with those at home.

\section{Cluster and outbreak investigations $(n=2)$}

\begin{tabular}{l|l} 
Larosa (2020) (19) & This cluster investigation analysed the transmission of
\end{tabular}

Cluster investigation

Italy

Sep-Oct 2020

Stein-Zamir (2020) (20)

Outbreak investigation

Israel

May-Jun 2020
COVID-19 in 41 classes of 36 schools upon their re-opening in northern Italy. The secondary attack rate was measured in students and teachers in elementary and secondary schools (middle and high schools). IPAC measures included: mask mandate for high school students only, physical distancing and ban of extracurricular activities.

This outbreak investigation study assessed the epidemiological characteristics of a high school outbreak in Jerusalem that displayed mass COVID-19 transmission upon school reopening on May 17. The high school included grades 7-12.

An extreme heatwave occurred upon the re-opening of the school. IPAC measures: face mask use was lifted for three days during the heatwave, physical distancing was below the standard in overcrowded classes, and extracurricular activities were not banned.
Secondary attack rate for COVID-19 was reported to be higher in secondary schools $(6.6 \%)$ than in elementary schools $(0.38 \%)$
It was reported that the proportion of the 10-19 year-olds was $19.8 \%(n=938 / 4,747)$ of the cases before May $24^{\text {th }}$, and then increased to $40.9 \%(n=316 / 772)$ after May $24^{\text {th }}$.

Testing of the whole school revealed that 153 students (attack rate: $13.2 \%$ ) and 25 staff members (attack rate: 16.6\%) were COVID-19 positive.

COVID-19 rates were higher in students in grades 7-9 than in grades 10-12. 


\section{Appendix Table A2: Summary of ecological studies assessing the effectiveness of school closures or re-openings on reducing spread of COVID-19 in the community $(n=19)$}

\begin{tabular}{|c|c|c|}
\hline Study & Method & Key outcomes \\
\hline \multicolumn{3}{|l|}{ Global $(n=10)$} \\
\hline $\begin{array}{l}\text { An (2021) (21) } \\
\text { Ecological study } \\
\text { Global } \\
\text { Jan-Jul } 2020\end{array}$ & $\begin{array}{l}\text { This study aimed to identify associations between six NPIs and } \\
\text { the number of COVID-19 infections. Using worldwide data on } \\
\text { NPIs and COVID-19 infections between Jan-Jul 2020, analysis was } \\
\text { conducted on the short- and long-term effects of NPIs on new } \\
\text { infection rates five, nine, } 12 \text {, and } 21 \text { days after their adoption. IPAC } \\
\text { measures and level of schooling included in the study were not } \\
\text { described. } \\
\text { NPIs examined included mask mandates, international travel } \\
\text { restrictions, domestic lockdowns, mass gathering bans, restaurant } \\
\text { closures and school closures. }\end{array}$ & $\begin{array}{l}\text { School closures took more time than other NPIs to show } \\
\text { efficacy. After a time lag, the impact of school closures on } \\
\text { new case rates was }-0.492(\mathrm{SE}=0.16) \text { at } 12 \text { days }(p<0.01) \text {, } \\
-0.722 \text { ( } \mathrm{SE}=0.148) \text { at } 21 \text { days }(p<0.001) \text {, and }-0.824 \\
(\mathrm{SE}=0.0967) \text { at } 30 \text { days ( } p<0.001) \text {. } \\
\text { School closures were not found to have significant effects } \\
\text { on population-adjusted infections in the long-term }\left(90^{\text {th }} \text { to }\right. \\
120^{\text {th }} \text { day). }\end{array}$ \\
\hline $\begin{array}{l}\text { Banholzer (2020) (27) } \\
\text { Ecological study } \\
20 \text { countries } \\
\text { Apr } 2020\end{array}$ & $\begin{array}{l}\text { In this study, the impact of NPIs on the relative reduction of } \\
\text { new COVID-19 cases using a Bayesian hierarchical model with } \\
\text { a time-delayed effect for each NPI. IPAC measures were not } \\
\text { described. } \\
\text { NPIs examined included 1) primary school closures, 2) border } \\
\text { closures, 3) public event bans, 4) gathering bans, 5) venue closures, } \\
\text { 6) lockdowns prohibiting public movements without valid reason } \\
\text { and 7) work bans on non-essential business activities. }\end{array}$ & $\begin{array}{l}\text { The mean reduction of new COVID-19 cases with primary } \\
\text { school closures was } 8 \% \text { ( } 95 \% \text { CI: } 0 \%-23 \%) \text {. } \\
\text { Compared with other NPIs examined, school closures } \\
\text { appeared to be one of the least effective NPIs. }\end{array}$ \\
\hline $\begin{array}{l}\text { Banholzer (2021) (26) } \\
\text { Ecological study } \\
20 \text { countries } \\
\text { Feb-May } 2020\end{array}$ & $\begin{array}{l}\text { Using a semi-mechanistic Bayesian hierarchical model, this study } \\
\text { aimed to measure the effectiveness of seven NPIs in reducing the } \\
\text { number of new infections. IPAC measures were not described. } \\
\text { NPls examined included 1) primary school closures, 2) border } \\
\text { closures, 3) public event bans, 4) gathering bans, 5) venue closures, } \\
\text { 6) lockdowns prohibiting public movements without valid reason } \\
\text { and 7) work bans on non-essential business activities. }\end{array}$ & $\begin{array}{l}\text { The relative reduction of new COVID-19 cases with } \\
\text { primary school closures was } 17 \% \text { ( } 95 \% \mathrm{Cl}: 2 \%-36 \%) \text {. } \\
\text { This reduction was lower than two other NPIs (event bans } \\
\text { and venue closures). }\end{array}$ \\
\hline $\begin{array}{l}\text { Brauner (2021) (28) } \\
\text { Ecological study } \\
41 \text { countries } \\
\text { Jan-May } 2020\end{array}$ & $\begin{array}{l}\text { This study estimated the effectiveness of NPIs in } 41 \text { countries } \\
\text { using a Bayesian hierarchical model by linking intervention } \\
\text { implementation dates to national case and death counts. } \\
\text { Intervention effect sizes were categorized by the median } \\
\text { reductions in the } R_{t} \text { of less than } 17.5 \% \text { (small), between } 17.5 \text { and } \\
35 \% \text { (moderate) and at least } 35 \% \text { (large). NPIs examined included: } \\
\text { limiting gatherings to fewer than } 1,000 \text { or fewer than } 100 \text { or fewer } \\
\text { than 10, closing some businesses, closing most businesses, closing } \\
\text { schools and universities, and stay at home orders. IPAC measures } \\
\text { were not described. }\end{array}$ & $\begin{array}{l}\text { The percentage reduction in } \mathrm{R}_{\mathrm{t}} \text { associated with closing } \\
\text { both schools and universities in conjunction was } 38 \% \text { (95\% } \\
\text { Cl: } 16 \%-54 \%), \text { which was categorized as a large effect } \\
\text { size. } \\
\text { The individual effects of school closures was not } \\
\text { measured. }\end{array}$ \\
\hline $\begin{array}{l}\text { Klimek-Tulwin (2020) (38) } \\
\text { Ecological study } \\
\text { Global } \\
\text { Mar } 2020\end{array}$ & $\begin{array}{l}\text { This study aimed to assess the effect of school closures on } \\
\text { COVID- } 19 \text { cases globally by measuring correlation between the } \\
\text { incidence rate on the day of school closure and the incidence } \\
\text { rate in the following days. IPAC measures and level of schooling } \\
\text { included in the study were not described. }\end{array}$ & $\begin{array}{l}\text { The results indicate that there was a strong correlation } \\
\text { between the day of educational facilities closure and } \\
\text { the incidence rate in the following days }\left(16^{\text {th }}(p=0.004) \text {, }\right. \\
30^{\text {th }}(p=0.002) \text { and } 60^{\text {th }}(p=0.031) \text { days since the } 100^{\text {th }} \\
\text { confirmed case in each country). } \\
\text { Early closure of schools is statistically significantly } \\
\text { correlated with lower incidence rates further on during the } \\
\text { different phases of the epidemic. }\end{array}$ \\
\hline $\begin{array}{l}\text { Papadopoulos (2020) (39) } \\
\text { Ecological study } \\
\text { Global } \\
\text { Jan-Apr } 2020\end{array}$ & $\begin{array}{l}\text { The impact of lockdown measures was assessed globally using } \\
\text { publicly available data. The timing and association of early NPIs } \\
\text { with } \log _{10} \text { national deaths }\left(\log _{\mathrm{D}}\right) \text { and } \log _{10} \text { national cases (Log } \mathrm{C} \text { ) } \\
\text { was compared between nations. IPAC measures and level of } \\
\text { schooling included in the study were not described. }\end{array}$ & $\begin{array}{l}\text { Early generalized school closure }(p=0.050 \text {, regression } \\
\text { coefficient } B=-0.012,95 \% \mathrm{Cl}: 0 \%--0.024 \%) \text { was associated } \\
\text { with reduced } \log _{C}\left(\log _{10} \text { national cases). }\right.\end{array}$ \\
\hline $\begin{array}{l}\text { Pasdar }(2020)(34) \\
\text { Ecological study } \\
22 \text { countries } \\
\text { May } 2020\end{array}$ & $\begin{array}{l}\text { The aim of this study was to determine the associations between } \\
\text { NPIs and COVID-19 outcomes. } \\
\text { Associations with NPIs were assessed with their respective } \\
\text { stringency index on several outcomes that form the epidemic } \\
\text { curve: mean mortality rate, time to peak, peak deaths per } 100,000 \\
\text { population, cumulative deaths after peak per } 100,000 \text { population } \\
\text { and ratio of the mean slope of the descending curve to the } \\
\text { mean slope of the ascending curve. IPAC measures and level of } \\
\text { schooling included in the study were not described. }\end{array}$ & $\begin{array}{l}\text { School closures were effective against all outcomes, } \\
\text { except time to reaching the peak of the epidemic curve. } \\
\text { The strongest association was seen in cumulative deaths } \\
\text { after peak, per } 100,000 \text { ( } r s=-0.744, p=0.009 \text { ). } \\
\text { In non-European countries, school closures were most } \\
\text { effective against mean mortality rate }(r s=-0.757, p=0.049 \text { ). }\end{array}$ \\
\hline $\begin{array}{l}\text { Esra (2020) (30) } \\
\text { Ecological study } \\
\text { Global } \\
\text { Jan-May } 2020\end{array}$ & $\begin{array}{l}\text { This study used globally reported data on SARS-CoV-2 cases to fit } \\
\text { a Bayesian model framework to estimate the association with NPIs } \\
\text { and transmission. } \\
\text { NPIs examined include stay home mandates, gathering limits, } \\
\text { school closures (primary, secondary and tertiary educational } \\
\text { institutions) and mask policies. IPAC measures were not described. }\end{array}$ & $\begin{array}{l}\text { There was an estimated mean reduction in } \mathrm{R}_{\mathrm{t}} \text { of } 12 \%(95 \% \\
\mathrm{Cl}: 5 \%-19 \%) \text { with school closures (primary, secondary and } \\
\text { tertiary educational institutions). }\end{array}$ \\
\hline
\end{tabular}


Appendix Table A2: Summary of ecological studies assessing the effectiveness of school closures or re-openings on reducing spread of COVID-19 in the community $(n=19)$ (continued)

\begin{tabular}{|c|c|c|}
\hline Study & Method & Key outcomes \\
\hline \multicolumn{3}{|l|}{ Global $(n=10)$ (continued) } \\
\hline $\begin{array}{l}\text { Jüni (2020) (40) } \\
\text { Ecological study } \\
\text { Global } \\
\text { Mar } 2020\end{array}$ & $\begin{array}{l}\text { This prospective study of geopolitical areas aimed to determine } \\
\text { whether climate or public health interventions are associated with } \\
\text { reducing transmission of COVID-19. } \\
\text { A weighted random effects regression was used to determine the } \\
\text { association between epidemic growth RRR and climate measures } \\
\text { and public health interventions such as school closures, restrictions } \\
\text { of mass gatherings and measures of social distancing during an } \\
\text { exposure period } 14 \text { days previously. IPAC measures and level of } \\
\text { schooling included in the study were not described. }\end{array}$ & $\begin{array}{l}\text { Strong negative associations with epidemic growth were } \\
\text { found for school closures (RRR - } 0.63,95 \% \\
\mathrm{Cl}: 0.52 \%-0.78 \% \text { ). } \\
\text { This association was more pronounced in areas that } \\
\text { implemented two or three NPIs compared with one NPI. }\end{array}$ \\
\hline $\begin{array}{l}\text { Stokes }(2020)(33) \\
\text { Ecological study } \\
\text { Global } \\
\text { Jun } 2020\end{array}$ & $\begin{array}{l}\text { This study examined the variation of NPIs in } 130 \text { countries in two } \\
\text { periods: 1) prior to first COVID-19 death and 2) 14-days-post first } \\
\text { COVID-19 death. } \\
\text { This study examined associations with daily COVID-19 deaths per } \\
\text { million and each } 24 \text { day period (time between virus transmission } \\
\text { and mortality). IPAC measures and level of schooling included in } \\
\text { the study were not described. }\end{array}$ & $\begin{array}{l}\text { Stricter/earlier school closures were associated with the } \\
\text { largest reductions in COVID-19 deaths }(-1.23 \text { per million } \\
\text { [95\% Cl: }-2.20 \%--0.27 \%]) \text { compared with other NPIs. }\end{array}$ \\
\hline \multicolumn{3}{|l|}{ North America $(n=5)$} \\
\hline $\begin{array}{l}\text { Auger (2020) (29) } \\
\text { Ecological study } \\
\text { US } \\
\text { Mar-May } 2020\end{array}$ & $\begin{array}{l}\text { This study aimed to determine if school closures were associated } \\
\text { with a decrease in the cumulative incidence of COVID-19 and } \\
\text { mortality. } \\
\text { The impact of primary and secondary school closures was assessed } \\
\text { using publicly available data from all } 50 \text { states. IPAC measures } \\
\text { were not described. }\end{array}$ & $\begin{array}{l}\text { Results showed that school closures were associated with } \\
\text { a significant decline in incidence of COVID-19 (-62\% [95\% } \\
\text { CI: -71\%--49\%]) and in mortality (-58\% [95\% } \\
\text { Cl: - }-68 \%-46 \%]) \text {. } \\
\text { These associations were stronger in states with a low } \\
\text { cumulative incidence of COVID-19 at the time of the } \\
\text { school closure. }\end{array}$ \\
\hline $\begin{array}{l}\text { Dreher (2020) (31) } \\
\text { Ecological study } \\
\text { US } \\
\text { Apr } 2020\end{array}$ & $\begin{array}{l}\text { This study aimed to measure the impact of NPIs on the effective } R_{t} \\
\text { of COVID-19 in US states. } \\
\text { The average } R_{t} \text { was measured during the weeks after each state } \\
\text { reached } 500 \text { cases. } R_{t} \text { was measured at the week immediately } \\
\text { following } 500^{\text {th }} \text { case (days }+1 \text { to }+7 \text { ) and at a one-week delay from } \\
500^{\text {th }} \text { case (days }+8 \text { to }+14 \text { ). } \\
\text { NPIs examined included stay at home order, educational facilities } \\
\text { closure and non-essential business closure. IPAC measures and } \\
\text { level of schooling included in the study were not described. }\end{array}$ & $\begin{array}{l}\text { Educational facilities closure was associated with a } \\
\text { significant reduction in } R_{t} \text { compared with states without } \\
\text { this policy the week following } 500 \text { cases } \\
\text { ( }(=-0.17,95 \% \mathrm{Cl}:-0.30 \%--0.05 \%, p=0.009 \text { ). } \\
\text { From days } 8 \text { to } 14 \text { after the } 500^{\text {th }} \text { case date, educational } \\
\text { facilities closure was associated with a significant } \\
\text { reduction in } R_{t} \text { compared with controls } \\
(B=-0.12,95 \% \mathrm{Cl}:-0.21 \%-0.04 \%, p=0.006) \text {. }\end{array}$ \\
\hline $\begin{array}{l}\text { Krishnamachari (2020) (41) } \\
\text { Ecological study } \\
\text { US } \\
\text { May } 2020\end{array}$ & $\begin{array}{l}\text { This study aimed to examine the effects of NPIs on the cumulative } \\
\text { incidence rates of COVID-19 in the US on a state-level in the } 25 \\
\text { most populated cities, while adjusting for socio-demographic risk } \\
\text { factors. } \\
\text { A negative binomial regression was used to calculate adjusted rate } \\
\text { ratios by comparing two levels of a binary variable: "above median } \\
\text { value," and "median value and below" for days to implementing } \\
\text { an NPI. } \\
\text { NPIs assessed in this study included: days to closing of non- } \\
\text { essential businesses, days to stay home orders, days to restrictions } \\
\text { on gatherings, days to restaurant closings and days to schools } \\
\text { closing. IPAC measures and level of schooling included in the study } \\
\text { were not described. }\end{array}$ & $\begin{array}{l}\text { Days to school closing was associated with cumulative } \\
\text { incidence on days } 35 \text { and } 42, \text { with an adjusted rate ratio } \\
\text { of } 1.59(95 \% \mathrm{Cl}: 1.03 \%-2.44 \%, p=0.04) \text { at } 35 \text { days, and } \\
\text { adjusted rate ratio of } 1.64(95 \% \\
\mathrm{Cl}: 1.07 \%-2.52 \%, p=0.04) \text { at } 42 \text { days. } \\
\text { Delays in closing schools was positively associated with } \\
\text { cumulative incidence at the state level. }\end{array}$ \\
\hline $\begin{array}{l}\text { Liu }(2020)(22) \\
\text { Ecological study } \\
\text { US } \\
\text { Feb-Apr } 2020\end{array}$ & $\begin{array}{l}\text { This study estimated the impact of nine different NPIs on } \\
\text { reduction of the effective } R_{t} \text { by using the daily number of } \\
\text { reported new cases and inferred infections in } 50 \text { states. IPAC } \\
\text { measures and level of schooling included in the study were not } \\
\text { described. }\end{array}$ & $\begin{array}{l}\text { Closing schools was found to moderately reduce } \mathrm{R}_{\mathrm{t}} \text { by } \\
\text { about } 10 \%(95 \% \mathrm{Cl} \text { : } 7 \%-14 \%) \text {. } \\
\text { This reduction was smaller than six other NPls } \\
\text { assessed (stay-at-home order, face masks, gathering } \\
\text { ban, non-essential business closure, declaration of } \\
\text { state of emergency and interstate travel restriction). }\end{array}$ \\
\hline $\begin{array}{l}\text { Yehya (2020) (35) } \\
\text { Ecological study } \\
\text { US } \\
\text { Jan-Apr } 2020\end{array}$ & $\begin{array}{l}\text { In this study, a state-level analysis was conducted to determine } \\
\text { association between later implemented NPIs with higher } \\
\text { mortality rates. } \\
\text { Using a multivariable negative binomial regression, the } \\
\text { association was tested between timing of emergency } \\
\text { declarations and school closures with } 28 \text {-day mortality. Day } 1 \\
\text { for each state was set to when they recorded } 10 \text { or more } \\
\text { deaths. IPAC measures and level of schooling included in the } \\
\text { study were not described. }\end{array}$ & $\begin{array}{l}\text { Later school closure was associated with more deaths } \\
\text { (adjusted mortality rate ratio } 1.05 ; 95 \% \mathrm{Cl} \text { : } \\
1.01 \%-1.09 \% ; p=0.008 \text { ). }\end{array}$ \\
\hline
\end{tabular}




\section{Appendix Table A2: Summary of ecological studies assessing the effectiveness of school closures or re-openings on reducing spread of COVID-19 in the community $(n=19)$ (continued)}

\begin{tabular}{|c|c|c|}
\hline Study & Method & Key outcomes \\
\hline \multicolumn{3}{|l|}{ Asia $(n=2)$} \\
\hline $\begin{array}{l}\text { Cowling (2020) (32) } \\
\text { Ecological study } \\
\text { Hong Kong } \\
\text { Jan-Feb } 2020\end{array}$ & $\begin{array}{l}\text { This study examined the effect of public health interventions } \\
\text { on the incidence of COVID-19 and on the daily effective } R_{t} \text {. } \\
\text { Laboratory-confirmed COVID-19 cases and the daily effective } \\
R_{t} \text { were estimated to determine changes in transmissibility } \\
\text { over time. School closures included kindergartens up to } \\
\text { tertiary and post-tertiary institutions, and tutorial centres. IPAC } \\
\text { measures were not described. }\end{array}$ & $\begin{array}{l}\left.\text { The estimated } \mathrm{R}_{\mathrm{t}} \text { was } 1.28 \text { ( } 95 \% \mathrm{Cl}: 1.26 \%-1.30 \%\right) \\
\text { during the } 2 \text {-week period before the start of the } \\
\text { school closures and } 0.72(95 \% \mathrm{Cl}: 0.70 \%-0.74 \%) \\
\text { during the first two weeks of school closures, } \\
\text { corresponding to a } 44 \% \text { ( } 95 \% \mathrm{Cl}: 34 \%-53 \% \text { ) reduction } \\
\text { in transmissibility. } \\
\mathrm{R}_{\mathrm{t}} \text { calculated from hospitalization data was } 1.10 \\
\text { (1.06-1.12) before the start of the school closures } \\
\text { and reduced to } 0.73(0.68-0.77) \text { after school closures, } \\
\text { corresponding to a } 33 \% \text { ( } 95 \% \mathrm{Cl}: 24 \%-43 \%) \text { reduction } \\
\text { in transmissibility. }\end{array}$ \\
\hline $\begin{array}{l}\text { Kentaro }(2020)(23) \\
\text { Ecological study } \\
\text { Japan } \\
\text { Mar } 2020\end{array}$ & $\begin{array}{l}\text { This study aimed to assess the effectiveness of primary and } \\
\text { secondary school closures on COVID-19 incidence nine days } \\
\text { after implementation. IPAC measures were not described. } \\
\text { Using a Bayesian method, time-series analyses were } \\
\text { conducted, and local linear trend models were developed for } \\
\text { the number of newly reported cases of COVID-19. }\end{array}$ & $\begin{array}{l}\text { The school closure intervention was not effective in } \\
\text { decreasing the incidence of COVID- } 19 \text {. } \\
\text { The newly reported COVID-19 cases continued to rise } \\
(\alpha-0.08,95 \% \mathrm{Cl}:-0.36 \%-0.65 \%) \text {. }\end{array}$ \\
\hline \multicolumn{3}{|l|}{ Europe $(n=2)$} \\
\hline $\begin{array}{l}\text { Wieland (2020) (24) } \\
\text { Ecological study } \\
\text { Germany } \\
\text { Mar-Apr } 2020\end{array}$ & $\begin{array}{l}\text { The aim of this study was to assess the effectiveness of } \\
\text { different NPIs against the spread of COVID-19 over time. } \\
\text { School closures included day-care closures as well. IPAC } \\
\text { measures were not described. } \\
\text { Using publicly available data on daily reported German } \\
\text { cases, exponential growth models for infections and } R_{t} \text { were } \\
\text { estimated and investigated with respect to change points in } \\
\text { the time series. }\end{array}$ & $\begin{array}{l}\text { No significant effect was found on COVID-19 } \\
\text { infections that could be attributed to school and } \\
\text { day-care closures. }\end{array}$ \\
\hline $\begin{array}{l}\text { Ehrhardt (2020) (25) } \\
\text { Ecological study } \\
\text { Germany } \\
\text { Feb-Aug } 2020\end{array}$ & $\begin{array}{l}\text { This study aimed to assess the transmission of SARS-CoV-2 } \\
\text { among children in primary schools, secondary schools and } \\
\text { childcare facilities in Baden-Württemberg, Germany after } \\
\text { school re-openings in May 2020. IPAC measures included: } \\
\text { reduced class size, disinfecting, hand hygiene and banning of } \\
\text { sports and music in primary and secondary schools. } \\
\text { An epidemic curve was used to show daily new cases after the } \\
\text { schools reopened. }\end{array}$ & $\begin{array}{l}\text { Child-to-child transmission in schools was low. } \\
\text { The study estimated that one secondary case } \\
\text { originates per } 25 \text { infectious school days (days that } \\
\text { cases spent at school during infectious period). } \\
\text { School re-openings were not associated with a change } \\
\text { in transmission of SARS-CoV-2. }\end{array}$ \\
\hline
\end{tabular}

Abbreviations: Cl, confidence interval; COVID-19, coronavirus disease 2019; IPAC, infection prevention and control; NPI, non-pharmaceutical intervention; RRR, ratios of rate ratios; $\mathrm{rs}$, respective stringency index; $\mathrm{R}_{\mathrm{t}^{\prime}}$ effective reproduction number; SARS-CoV-2, severe acute respiratory syndrome coronavirus 2; $\mathrm{SE}$; standard error; US, United States 